\title{
Impact of Dividend Policy on Shareholder Wealth
}

\author{
AsmaTahir, NainTaraSarfarz Raja \\ MBA (1.5 Yrs.), Foundation University Islamabad, Pakistan. \\ Assistant Professor, Foundation University Islamabad, Pakistan.
}

\begin{abstract}
The present paper is aimed at analyzing the impact of dividend policy on shareholder wealth of oil and gas exploration companies of Pakistan during the years from 1999 to 2006. Statistical tools are used in this research including regression and correlation methods to ascertain best fitted model for predicting the dividend policy impact on shareholders wealth, by taking dividend payout ratio, P/E ratio and BV/MV equity ratio as independent variables and holding period yield as dependent variable. To determine the proportion of explained variation in dependent variable, the coefficient of determination has been tested with the help of $F$ test. The result indicates based on historical data and statistical analysis that correlation between independent variables and depended variable is very low for all companies showing insignificant relationship between them. Keyword: Dividend payout ratio, holding period yield, oil and gas, Price to earnings ratio, shareholder wealth .
\end{abstract}

\section{Introduction}

Oil and gas sector is a key to economic growth by fuelling manufacturing, agriculture, power and service sectors. On the basis of these reasons it has attracted the concentration of the present government. Because of developing country, demand for energy has increased where industries need more support from government and foreign investment. The Government of Pakistan has prepared a broad plan to drill 100 wells a year with a view to boosting oil \& gas production and simultaneously adopting liberal policy of encouraging foreign and local investment in oil and gas exploration program. Researchers explained that shareholder value is created when financial benefits of activities overcome the cost of these activities. This indicates the importance of dividend policy and its importance on market price of share because dividend increase will increase the market value of share which automatically affects the wealth of a shareholder and investors will get more return on investment.

History reflects the behavior of investors that many of the investors depend on dividend payout ratio. Investors like to invest in companies which pay high dividend because they want maximum return but from the firm point of view continuous high dividend payout creates hurdles and increase the financial cost. High dividend payout companies reduce payout at a certain level to maintain the financial position of the firm (Business Week, 2009). It is the major difference between an investor and a speculator that a speculator wants to take risk in response of abnormal return while an investor is more concerned with consistent performance of that asset in which he has invested his fund. This consistent performance of an asset (security) is dependent on the performance of the policies of the managers.

The main responsibility of the financial manager is to maximize the shareholders wealth and it's very important for him to have good understanding of dividend and dividend policy because any good and bad decision about dividend can affect the wealth of shareholder .Dividend policy has great importance in firm progress because a dividend signals towards firm stability and its long term attention of business. Capital structure of the firm is also affected by dividend and recently investors analyze opportunities on the basis of dividend. Previous literature indicates that the firms which paid dividends have higher value of share in the market.

Our sample represents all the spheres of oil and gas sector including oil and gas exploration companies, refineries and marketing and distributing companies therefore this research represents the sector as a whole and provides investor necessary information for future return on their investment. Investors can utilize this study to invest in oil and gas sector of Pakistan and they can understand the return fluctuations as a result of dividend policy therefore this research will helpful to investors in future.

Prime objective of this research is to find out different factors related to the dividend policy like (payout ratio, book value to market value, \& price earnings ratio) and their impact on shareholder wealth. To help out managers to find best fit dividend policy for their company it leads to maximize shareholder wealth. To inform the investors about significant factors of dividend policy effecting their wealth.

This study is helpful for investors to understand the significance of dividend related decisions of management and impact of these decisions on their wealth. As well as it is important for managers to formulate best policy and implement it with proper evaluation and control. Managers have to decide how much dividend they have to pay to get the trust of shareholder that company is progressive. Other way around they have to cut 
the dividend and reduce financial cost or extra burden on the company to maintain the retained earnings. This study gives clear idea to investors that how dividend policy is important to get maximum return on investment. This study will help the companies in oil and gas industry of Pakistan in increasing the shareholders wealth by understanding important factors of dividend policy.

\section{Research Question:}

Does the dividend policy affect the shareholders wealth in oil and gas sector of Pakistan?

\section{Literature Review}

Dividend is important variable in UK market because dividend announcement raises the market value of the share which results in wealth maximization due to positive change in dividend (Al-Twaijry, 2006). Dividend decisions plays vital role to forecast the future of a firm and also has great impact on the market price of the share. This indicates that decisions associated with dividend are very important for shareholder wealth maximization (Anand, 2004).

An increase in dividend payout is effective for a firm because it enhances the market price of the share and has great impact on shareholders wealth (Asquith \& Mullin, 1983). Shareholders consider dividends as an important factor because dividend has great impact on their wealth maximization. Higher dividend payout ratio creates positive reaction to market price of the share and there is an increase of price of share in market (Azhagaiah\&Priya, 2008).

Dividend announcement creates positive atmosphere in the market for investors because it is the signal for higher return and investors are interested in that signal because it mitigates the risk for investors and make their investment more secure. Researchers indicate that an investor should keep eye on dividend announcement because market gives abnormal return with announcement of increase in dividend (Below \& Johnson, 1996).

Researchers argued that market price of stock increases due to increase in dividend payment because it mitigates the systematic risk (Grullon, Michaely\&Swaminathan, 2000).High growth firms which wants to reduce financial costs has low dividend payout ratio because these firms want to maximize the profitability of firm and they try to minimize the financial costs (Jensen, Solberg \& Zorn, 1992).

A stock option to managers is a part of dividend policy which has positive relation to market price of the share and reduce corporate dividend (Kouki, 2009). During the financial crisis stock exchange listed companies can manage the market price of share by repurchasing the outstanding stocks, majority stock holders should buy more stocks and grant of stocks to senior manager should be more to making stable the market price of share (Lan, 2008).

After the year 2000 there is an increase in dividend payout ratio which results in an increase in stock return especially in information technology sector which has rapid increase in dividend payout ratio and this increases the return for stock (Sung, Kim \&Chincarini, 2006). Buying and holding stocks gives abnormal return to the investors. Researchers explained that short holding period results in abnormal returns (Higson\& Elliot, 1998).

Announcement of dividend increase, sends good news and it increase the price of the share in market therefore dividend increase announcement also increases the market price of the share (Elfakhani, 1995). This reflects that increase in share price will increase the shareholders wealth and holding period will give more return to investor.

Companies' main objective is to maximize the shareholders wealth by increasing the share price in the market; this gives abnormal returns to investor for holding period. According to the researchers an announcement in increase of cash dividend or stock dividend provides abnormal return which plays an important role to increase in market price of share (Travlos, Trigeorgis\&Vafeas, 2001).

\section{Theoretical Framework}

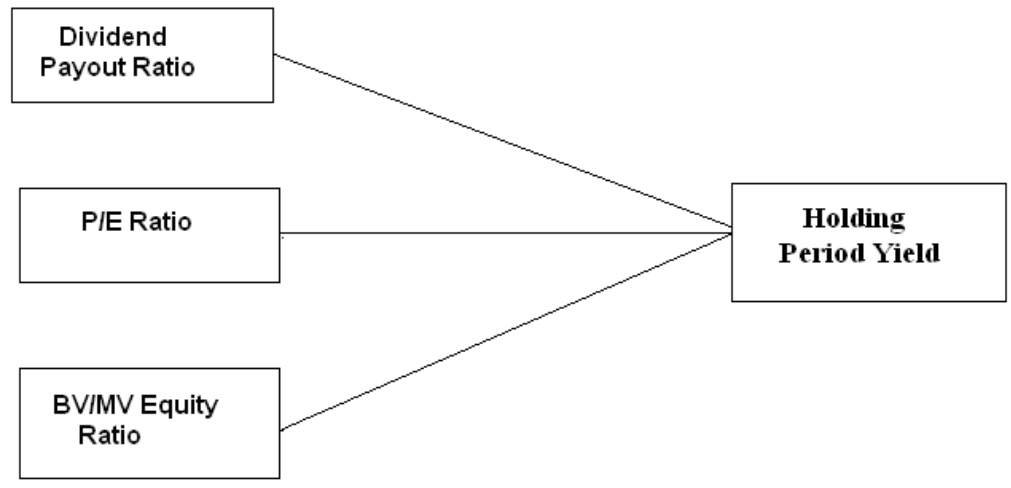




\section{Hypothesis:}

H1: There is strong positive significant relation between dividends payout ratio and Holding period yield in oil \& gas sector of Pakistan.

H2: P/E ratio has positive significant relation with holding period yield in oil and gas sector of Pakistan.

H3: There is positive significant relation between BV/MV and Holding period yield.

\section{Methodology}

Population

The population of this research is oil and gas industry of Pakistan.

\section{Sample and Sampling Techniques}

Our sample includes two oil and gas exploration companies, two refineries and two oil and gas marketing and distributing companies.

- Mari Gas Co Ltd

- Pakistan Oilfields Ltd

- $\quad$ Attock Refinery

- National Refinery

- Pakistan State Oil Ltd

- Shell Pakistan Ltd

Convenience sampling technique is used and we selected two exploration companies out of four and similarly selected two refineries out of four and two marketing and distributing companies out of seven listed on Karachi stock exchange. Out of 15 oil and gas marketing, exploration and refineries KSE listed companies we choose six above mentioned companies on availability of their data.

Data Collection and Data Collection Instruments

Data used in this research is secondary data and collected from following sources

- Karachi stock exchange website (www.kse.com.pk)

- Business Recorder

- National/International journals

- State Bank of Pakistan (SBP)

- Annual reports of selected companies

- Internet

\section{Data Analysis Techniques/Tools}

\section{Results and Discussion}

Statistical tools are used in this research including regression and correlation methods to ascertain best fitted model for predicting the dividend policy impact on shareholders wealth.

Table: 1

\begin{tabular}{|c|c|c|c|c|}
\hline \multicolumn{5}{|c|}{ MARI GAS LTD } \\
\hline Years & $\begin{array}{l}\text { Dividend } \\
\text { Payout Ratio } \\
(\%)\end{array}$ & P/E Ratio (\%) & $\begin{array}{l}\text { BV/MV of } \\
\text { Equity }\end{array}$ & HPY \\
\hline 1999 & 90.33 & 7.19 & 0.143017 & 0.143017 \\
\hline 2000 & 88.37 & 7.07 & 0.167778 & -0.17313 \\
\hline 2001 & 86.11 & 8.36 & 0.158352 & 0.056178 \\
\hline 2002 & 83.52 & 10.45 & 0.111052 & 0.298704 \\
\hline 2003 & 79.16 & 17.69 & 0.134526 & -0.21138 \\
\hline 2004 & 74.19 & 20.41 & 0.081807 & 0.391888 \\
\hline 2005 & 68.5 & 43.76 & 0.020647 & 0.747612 \\
\hline 2006 & 61.29 & 25.02 & 0.056126 & -1.71836 \\
\hline
\end{tabular}




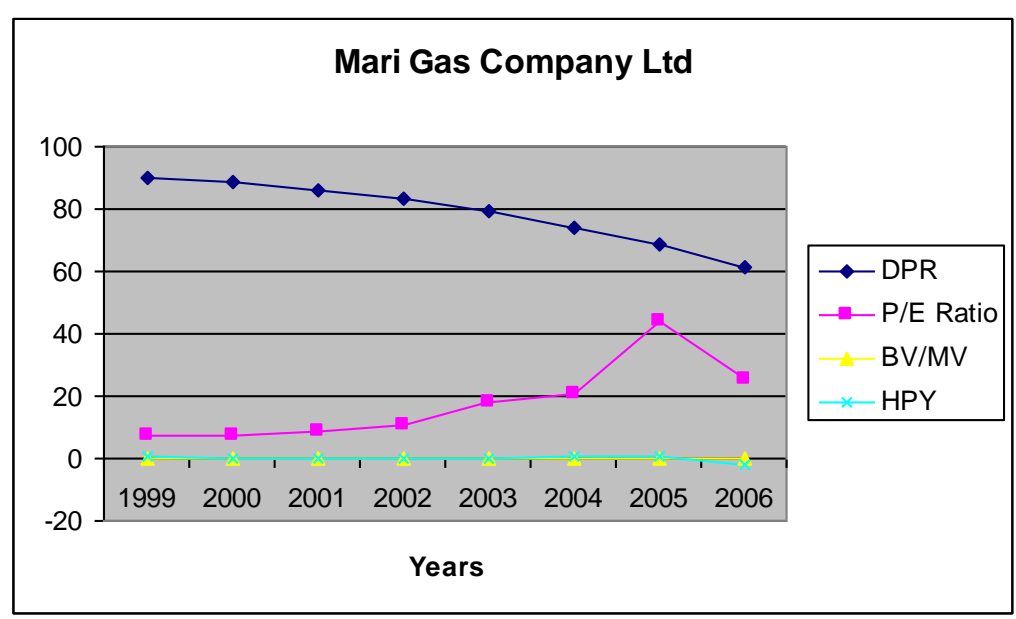

Graph of Mari Gas Company describe that there was not huge return for Mari Gas because dividend payout ratio decreased throughout and holding period return can increased if dividend payout ratio increased. Holding period yield decreased gradually from year 1999 to 2005 and in the end year 2006 represents huge decrease in holding period yield as graph shows towards negative values. In 1999 and 2000 P/E ratio was low due to which dividend payout ratio was high for the company and gradually P/E ratio increased and dividend payout ratio decreased. There is no significant change in book to market value of the company therefore holding period return for the company not increased too much it almost the same from 1999 to 2006. Overall graph value represents that does not attain holding period yield as it should be. This is due to the some other factors which affects the company's return. Law and order situation and political uncertainty disturbed the market and return for the company was not too high.

Table: 2

\begin{tabular}{|l|l|l|l|l|}
\hline \multicolumn{5}{|l}{ PAKISTAN OILFIELDS LTD } \\
\hline Years & $\begin{array}{l}\text { Dividend } \\
\text { Payout Ratio } \\
\%)\end{array}$ & P/E Ratio (\%) & $\begin{array}{l}\text { BV/MV of } \\
\text { Equity }\end{array}$ & HPY \\
\hline 1999 & 43.47 & 11.49 & 0.167037 & 0.167037 \\
\hline 2000 & 42 & 5.03 & 0.052231 & 0.687306 \\
\hline 2001 & 44 & 2.32 & 0.075851 & -0.4522 \\
\hline 2002 & 67.54 & 5.34 & 0.061897 & 0.183959 \\
\hline 2003 & 59.19 & 7.62 & 0.04214 & 0.319189 \\
\hline 2004 & 65.84 & 10.98 & 0.027338 & 0.35126 \\
\hline 2005 & 43.66 & 9.83 & 0.03049 & -0.11531 \\
\hline 2006 & 40.22 & 10.77 & 0.022133 & 0.274112 \\
\hline
\end{tabular}

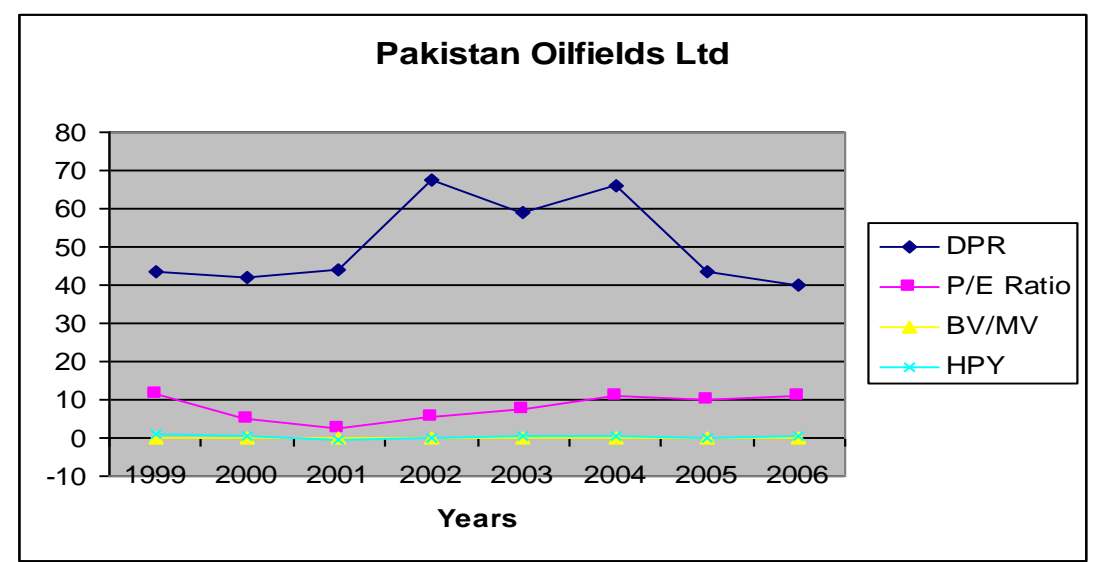

Pakistan Oilfields Ltd had fluctuation in dividend payout ratio from year 1999 to 2006. In $2001 \mathrm{P} / \mathrm{E}$ ratio decreased to 2.32 and dividend payout ratio increased to 44 . After this with little increased and decreased in P/E ratio dividend payout ratio also fluctuated. Book to market value of Pakistan Oilfields Ltd was almost constant and very minor changes in value did not affect the holding period yield of the company and that was the reason that dividend payout ratio did not created its impact on the return of the company. 
Table:3

\begin{tabular}{|l|l|l|l|l|}
\hline PAKISTAN STATE OIL LTD & P/E Ratio (\%) & $\begin{array}{l}\text { BV/MV of } \\
\text { Equity }\end{array}$ & HPY \\
\hline Years & $\begin{array}{l}\text { Dividend Payout } \\
\text { Ratio (\%) }\end{array}$ & P/ & 0.079135 & 0.079135 \\
\hline 1999 & 58.8 & 5.5 & 0.03694 & 0.533205 \\
\hline 2000 & 64.1 & 10.4 & 0.053434 & -0.44651 \\
\hline 2001 & 63.3 & 8.4 & 0.057071 & -0.06807 \\
\hline 2002 & 80.7 & 7.5 & 0.035289 & 0.38167 \\
\hline 2003 & 68.1 & 9.7 & 0.03419 & 0.031141 \\
\hline 2004 & 71.3 & 10.4 & 0.027927 & 0.183169 \\
\hline 2005 & 78.8 & 11.6 & 0.038964 & -0.3952 \\
\hline 2006 & 77.5 & 7 & & \\
\hline
\end{tabular}

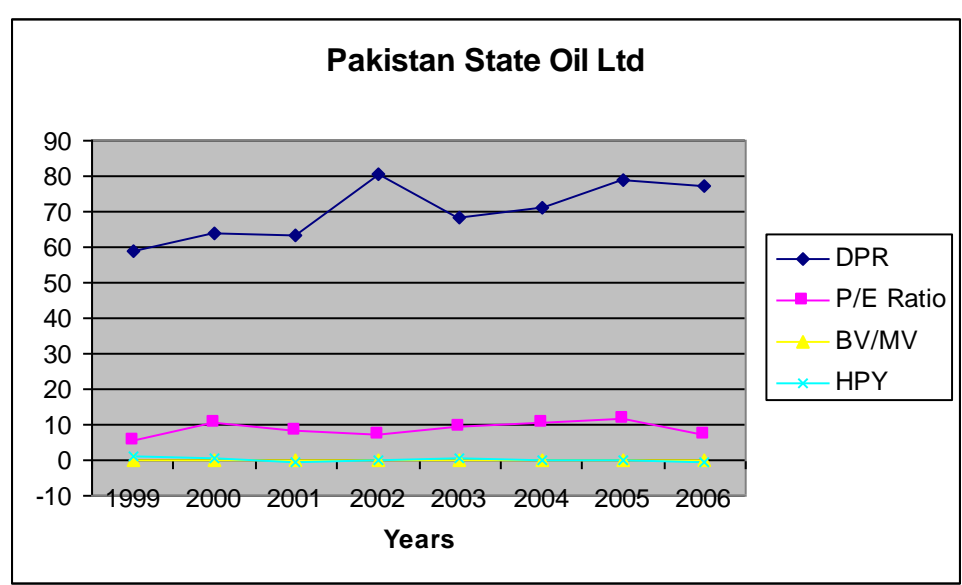

Pakistan State Oil Ltd graph represents that in 1999 dividend payout ratio of the company was 58.8 which increased in 2000 to 64.1 and again in 2001 payout ratio fell down to 63.3. There was huge increased in dividend payout ratio and the value was 80.7 in 2002 this was due to decreased in price earnings ratio because it was 8.4 in 2001 which decreased to 7.5. Holding period yield was higher in 1999 and then there was no significant difference in the return of the company. There was a not big change in the Book to market values of the company from 1999 to 2006 and this also affects the holding period yield and there were not high returns for the company.

Table: 4

\begin{tabular}{|c|c|c|c|c|}
\hline \multicolumn{5}{|c|}{ SHELL PAKISTAN LTD } \\
\hline Years & $\begin{array}{l}\text { Dividend } \\
\text { Payout } \\
\text { Ratio (\%) } \\
\end{array}$ & P/E Ratio (\%) & $\begin{array}{l}\text { BV/MV of } \\
\text { Equity }\end{array}$ & HPY \\
\hline 1999 & 49.8 & 6.4 & 0.079135 & 0.07439 \\
\hline 2000 & 44.59 & 7 & 0.03694 & 0.27285 \\
\hline 2001 & 41.52 & 9.3 & 0.053434 & -0.02165 \\
\hline 2002 & 59.4 & 7.3 & 0.057071 & -0.35392 \\
\hline 2003 & 97.76 & 11.8 & 0.035289 & 0.470704 \\
\hline 2004 & 81.39 & 8.1 & 0.03419 & -0.26723 \\
\hline 2005 & 62.61 & 9.9 & 0.027927 & 0.139116 \\
\hline 2006 & 52.26 & 8.4 & 0.038964 & -0.10361 \\
\hline
\end{tabular}




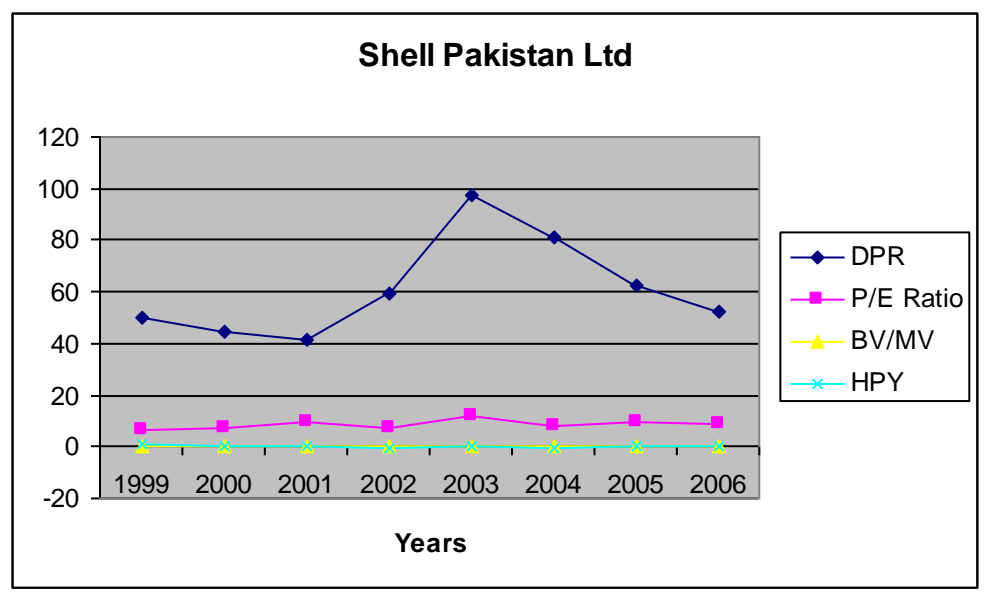

Shell Pakistan Ltd graph represents that dividend payout ratio was 49.8 in 1999 and it's decreased to 44.59 in 2000. Holding period yield decreased in 2001 due to decrease in dividend payout ratio in that year. P/E ratio also increased to 9.3 in the same year which decreased the return and dividend payout ratio of the company. There was not impactable increased and decreased in Book to market value which also created same effect to holding period yield and the return was not significant.

Table: 5

\begin{tabular}{|l|l|l|l|l|}
\hline \multicolumn{2}{|c|}{ ATTOCK REFINERY LTD } & & \\
\hline Years & $\begin{array}{l}\text { Dividend } \\
\text { Payout } \\
\text { Ratio (\%) }\end{array}$ & P/E Ratio (\%) & $\begin{array}{l}\text { BV/MV of } \\
\text { Equity }\end{array}$ & HPY \\
\hline 1999 & 64.78 & 33 & 0.369501 & 0.630499 \\
\hline 2000 & 98.17 & 25.91 & 0.35 & 0.052778 \\
\hline 2001 & 99.15 & 16.27 & 0.429268 & -0.22648 \\
\hline 2002 & 17.7 & 2.33 & 0.065144 & 0.848245 \\
\hline 2003 & 52.13 & 9.97 & 0.045084 & 0.307936 \\
\hline 2004 & 37.2 & 6.81 & 0.056284 & -0.24844 \\
\hline 2005 & 14.31 & 4.84 & 0.048417 & 0.139781 \\
\hline 2006 & 34.57 & 16.48 & 0.060455 & -0.24863 \\
\hline
\end{tabular}

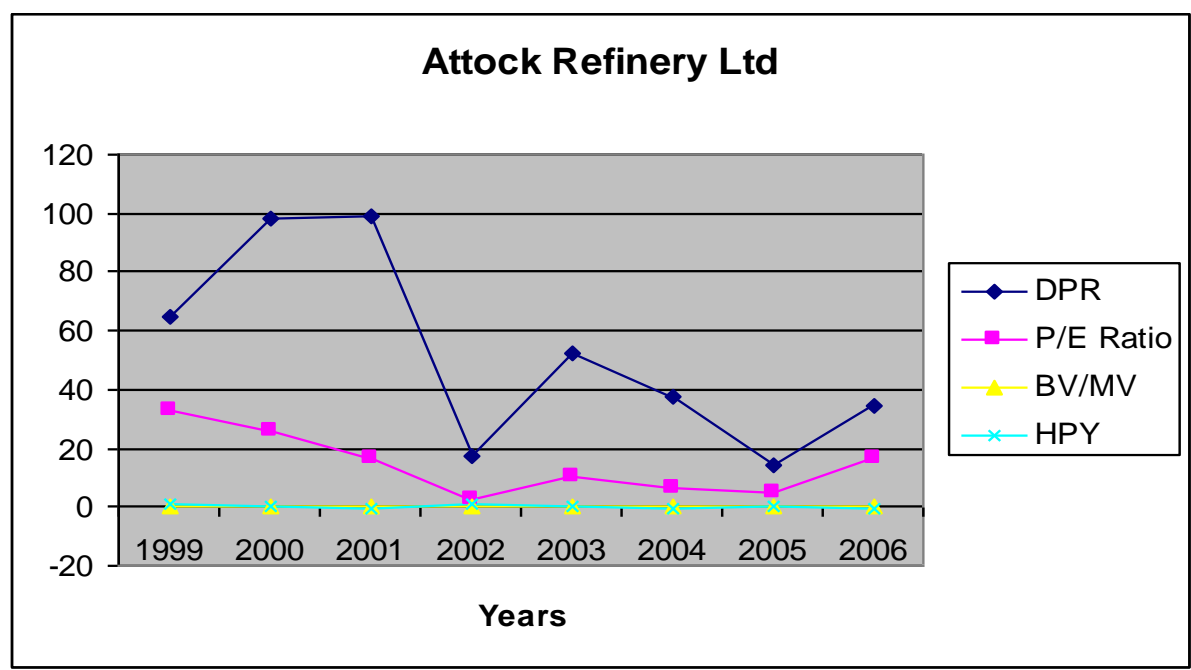

Dividend payout ratio of Attock Refinery Ltd was 64.78 in 1999 which increased to 98.17 due to decreased in $\mathrm{P} / \mathrm{E}$ ratio which came to 25.91 from 33. After 2001 there was fluctuation in dividend payout ratio. Companies Book to market value had no significant increased and decreased in values from 1999 to 2006 and it's also effected holding period yield very minor and the value of holding period yield shows that there was not huge return for the company. 
Table: 6

\begin{tabular}{|l|l|l|l|l|}
\hline \multicolumn{2}{|l}{ NATIONAL REFINERY LTD } \\
\hline Years & $\begin{array}{l}\text { Dividend Payout } \\
\text { Ratio (\%) }\end{array}$ & P/E Ratio (\%) & $\begin{array}{l}\text { BV/MV of } \\
\text { Equity }\end{array}$ & HPY \\
\hline 1999 & 41.44 & 4.02 & 0.369501 & 0.630499 \\
\hline 2000 & 42.94 & 3.35 & 0.35 & 0.052778 \\
\hline 2001 & 51.21 & 4.78 & 0.429268 & -0.22648 \\
\hline 2002 & 49.29 & 4.88 & 0.065144 & 0.848245 \\
\hline 2003 & 45.05 & 6.67 & 0.045084 & 0.307936 \\
\hline 2004 & 45.04 & 9.94 & 0.056284 & -0.24844 \\
\hline 2005 & 39.28 & 5 & 0.048417 & 0.139781 \\
\hline 2006 & 31.26 & 5.45 & 0.060455 & -0.24863 \\
\hline
\end{tabular}

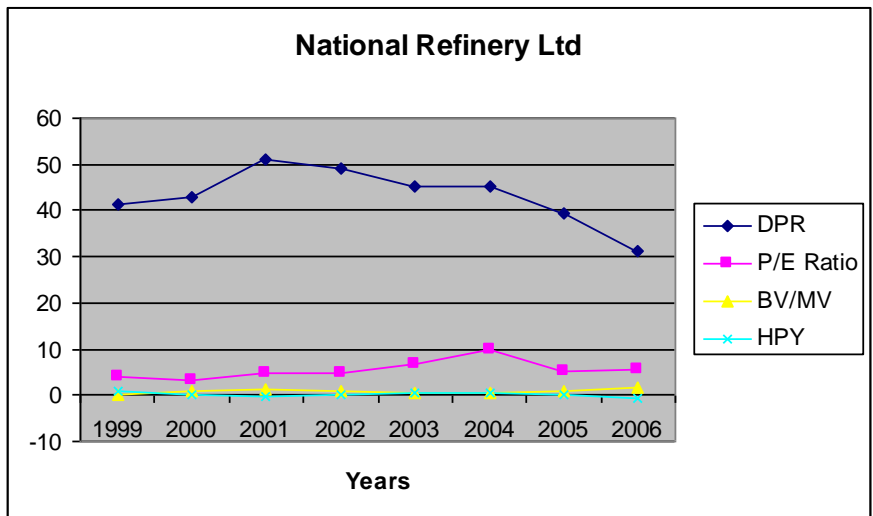

Graph for National Refinery Ltd describes that company's dividend payout ratio was 41.44 in 1999 which increased to 42.94 in 2000 due to decreased in the value of $\mathrm{P} / \mathrm{E}$ ratio because high dividend payout ratio increased holding period return for the company. Dividend payout ratio increased to 51.52 in 2001 due to little increase in Book to market value equity which increased from 0.35 to 0.42 . In 2003 and 2004 dividend payout ratios were almost same and due to decreased in Book to market value of equity holding period yield decreases which decreased the return for the company.

\section{Correlation Analysis}

\begin{tabular}{|l|r|r|r|r|}
\hline MARI GAS LTD & & & & \\
\hline & \multicolumn{1}{|l|}{ Intercept } & \multicolumn{1}{l|}{ Beta } & \multicolumn{1}{l|}{ F-test } & \multicolumn{1}{l|}{ Correlation } \\
\hline dividend payout ratio & 79.27413 & 5.850041 & $3.69867 \mathrm{E}-07$ & 0.422293613 \\
\hline P/E ratio & 17.57769 & 1.442744 & $8.98391 \mathrm{E}-08$ & 0.08496927 \\
\hline BV/MV of equity & 0.109268 & 0.001804 & $3.15593 \mathrm{E}-07$ & 0.025565286 \\
\hline
\end{tabular}

Statistical analysis shows insignificant correlation between independent variables, (dividend payout ratio, price to earnings ratio and book to market value) and dependent variable holding period yield for MARI GAS LTD. As you can see in table that correlation between dividend payout ratio and holding period yield is 0.42 which is insignificant. It also shows that $42 \%$ of variation in holding period yield is due to the dividend payout ratio and $58 \%$ of variation cause by other factors. Correlation between Price earnings ratio, BV/MV ratio and holding period yield is 0.08 and 0.025 respectively showing insignificant relationship with dependent variable.

\begin{tabular}{|l|r|r|r|r|}
\hline $\begin{array}{l}\text { PAKISTAN OILFIELDS } \\
\text { LTD }\end{array}$ & & & & \multicolumn{1}{l|}{} \\
\hline & \multicolumn{1}{|l|}{ Intercept } & \multicolumn{1}{l|}{ Beta } & \multicolumn{1}{l|}{ F-test } & \multicolumn{1}{l|}{ Correlation } \\
\hline dividend payout ratio & 49.6698 & 6.049082 & $7.3288 \mathrm{E}-10$ & 0.178871251 \\
\hline P/E ratio & 7.436195 & 2.748742 & $3.5067 \mathrm{E}-06$ & 0.274623854 \\
\hline BV/MV of equity & 0.063921 & -0.02279 & $3.34248 \mathrm{E}-05$ & -0.164105525 \\
\hline
\end{tabular}

Statistical analysis shows insignificant correlation between independent variables, (dividend payout ratio, price to earnings ratio and book to market value) and dependent variable holding period yield for PAKISTAN OIL FIELDS LTD. As you can see in table that correlation between dividend payout ratio and holding period yield is 0.17 which is insignificant. It also shows that $17 \%$ of variation in holding period yield is due to the dividend 
payout ratio and $83 \%$ of variation cause by other factors. Correlation between Price earnings ratio, BV/MV ratio and holding period yield is 0.27 and -0.16 respectively showing insignificant relationship with dependent variable.

\begin{tabular}{|l|r|r|r|r|}
\hline PAKISTAN STATE OIL LTD & & \multicolumn{1}{l|}{} & \multicolumn{1}{l|}{} \\
\hline & \multicolumn{1}{|l|}{ Intercept } & \multicolumn{1}{|l|}{ Beta } & \multicolumn{1}{l|}{ F-test } & \multicolumn{1}{c|}{ Correlation } \\
\hline dividend payout ratio & 70.50265 & -4.7606 & $8.96654 \mathrm{E}-09$ & -0.201461341 \\
\hline P/E ratio & 8.699934 & 3.016442 & 0.000111637 & 0.50074548 \\
\hline BV/MV of equity & 0.045873 & -0.01351 & $2.56796 \mathrm{E}-08$ & -0.274636176 \\
\hline
\end{tabular}

Statistical analysis shows insignificant correlation between independent variables, (dividend payout ratio, price to earnings ratio and book to market value) and dependent variable holding period yield for PAKISTAN STATE OIL LTD. As you can see in table that correlation between dividend payout ratio and holding period yield is 0.20 which is insignificant. It also shows the dividend payout ratio is negatively correlated with holding period yield. Correlation between Price earnings ratio, BV/MV ratio and holding period yield is 0.50 and -0.27 respectively showing insignificant relationship with dependent variable.

\begin{tabular}{|l|r|r|r|r|}
\hline SHELL PAKISTAN LTD & \multicolumn{1}{l|}{} & \multicolumn{1}{l|}{} \\
\hline & \multicolumn{1}{|l|}{ Intercept } & \multicolumn{1}{l|}{ Beta } & \multicolumn{1}{l|}{ F-test } & \multicolumn{1}{l|}{ Correlation } \\
\hline dividend payout ratio & 60.73214 & 16.4865 & $4.17385 \mathrm{E}-12$ & 0.232867712 \\
\hline P/E ratio & 8.439349 & 3.252832 & $7.06265 \mathrm{E}-05$ & 0.504459416 \\
\hline BV/MV of equity & 0.045752 & -0.01457 & $1.22727 \mathrm{E}-07$ & -0.236578838 \\
\hline
\end{tabular}

Statistical analysis shows insignificant correlation between independent variables, (dividend payout ratio, Price to earnings ratio and book to market value) and dependent variable holding period yield for SHELL PAKISTAN LTD. Table shows the correlation between dividend payout ratio and holding period yield is 0.23 . It showing $23 \%$ of variation in holding period yield is caused by the dividend payout ratio and $77 \%$ is caused by other factors. Correlation between Price earnings ratio, BV/MV ratio and holding period yield is 0.50 and -0.23 respectively showing insignificant relationship with dependent variable.

\begin{tabular}{|l|r|r|r|r|}
\hline ATTOCK REFINERY LTD & & & & \\
\hline & \multicolumn{1}{|l|}{ Intercept } & \multicolumn{2}{|l|}{ Beta } & \multicolumn{2}{l|}{ F-test } & \multicolumn{1}{c|}{ Correlation } \\
\hline dividend payout ratio & 55.72376 & -22.1233 & $1.87333 \mathrm{E}-12$ & -0.278685848 \\
\hline P/E ratio & 14.41542 & 0.228241 & $1.87333 \mathrm{E}-12$ & 0.008880526 \\
\hline BV/MV of equity & 0.180923 & -0.0185 & 0.03198064 & -0.044956469 \\
\hline
\end{tabular}

Statistical analysis shows insignificant correlation between independent variables, (dividend payout ratio, Price to earnings ratio and book to market value) and dependent variable holding period yield for ATTOCK REFINERY LTD. Correlation between dividend payout ratio and holding period yield is -0.27 which shows the negative insignificant relationship between two variables. Correlation between Price earnings ratio, BV/MV ratio and holding period yield is 0.008 and -0.044 respectively showing insignificant relationship with dependent variable.

\begin{tabular}{|l|r|r|r|r|}
\hline NATIONAL REFINERY LTD & & & & \\
\hline & \multicolumn{1}{|l|}{ Intercept } & \multicolumn{1}{|l|}{ Beta } & \multicolumn{1}{l|}{ F-test } & \multicolumn{1}{c|}{ Correlation } \\
\hline dividend payout ratio & 42.57024 & 3.940544 & $2.22698 \mathrm{E}-07$ & 0.264422502 \\
\hline P/E ratio & 5.799265 & -1.83494 & 0.00044247 & -0.374792926 \\
\hline BV/MV of equity & 0.180923 & -0.0185 & 0.03198064 & -0.044956469 \\
\hline
\end{tabular}

Statistical analysis shows insignificant correlation between independent variables, (dividend payout ratio, price to earnings ratio and book to market value) and dependent variable holding period yield for NATIONAL REFINERY LTD. Correlation between dividend payout ratio and holding period yield is 0.26 which showing positive but insignificant relationship between two variables. It also predicts $26 \%$ variation is caused by dividend payout ratio in holding period yield and $74 \%$ variation by other factors. Correlation between Price earnings ratio, BV/MV ratio and holding period yield is -0.37 and -0.044 respectively showing insignificant relationship with dependent variable. 


\section{Discussion}

The purpose of this study was to examine the relationship between Dividend payout ratio, P/E ratio, BV/MV ratio and holding period yield within oil and gas industry of Pakistan and how these variables effects shareholders wealth. The result indicates based on historical data and statistical analysis that correlation between independent variables and depended variable is very low for all companies showing insignificant relationship between them. These results contradict our hypothesis because Pakistan economy is under government influenced and there is bureaucratic style in organizations due to which holding period returns are not efficient. Privatization of the companies was at initial level during our selected period for research and there were lack of foreign investment due to which holding period return fluctuates. Although companies within oil and gas industry of Pakistan pay dividend on regular basis but there is uncertainty in stock market due to which holding period returns were not efficient because share price of companies were not stable and fluctuation took place in companies dividend payout ratio as a result dividend payout ratio had not significant relation with holding period yield. P/E ratio also fluctuates due to fluctuation in dividend and share price and also had insignificant relation with holding period yield this also contradict our $2^{\text {nd }}$ hypothesis. In efficient markets market capitalization increase with the passage of time and they also increases their book value because there is no uncertainty and investors are investing on regular basis but in Pakistan there is uncertainty in market which effects market capitalization and it is very hard for companies to increase market capitalization and their book value almost same for the number of years which effected holding period returns of companies and there is no significant relation between BV/MV and holding period yield.

\section{Conclusion}

Pakistan is an underdeveloped country and it's still facing lot of internal problems due to which stock markets of country are not consistent. Karachi stock market is the biggest stock market of a country but there is uncertainty in the market due to internal disturbance, political and law and order situation in the country. Investors are hesitating to invest especially foreign investors who can boost our economy. Pakistan is good investment market having potential to grow but environment of uncertainty is the great hurdle in its progress. Companies within oil and gas sector of Pakistan is paying dividend to attract the investors but they are maintaining their payout ratio and there is lot of fluctuation due to which holding period returns are not efficient. As our results indicate that there are many external factors influencing Karachi stock exchange and shareholders wealth is affected by these factors.

Country law and order situation and political uncertainty is there due to which investors are hesitating to invest which is effecting holding period yield within oil and gas sector of Pakistan. There is strong need to explore other factors which are effecting holding period yield within oil and gas industry of Pakistan.

The dependent variable holding period yield varies due certain political and economic factors. Moreover the instability in the market is one of the major causes of fluctuation in holding period yield. The risk of not realizing the expected yield cause by these factors is called systematic risk and investor is not compensated for that type of risk.

\section{References}

[1]. Al-Twaijry, A., A., M., (2006). An Analysis of the Relationships among Stock Prices (and Returns), Dividends and Earnings in the UK Stock Market. J. King Saud Univ., Vol. 18, Admin.Sci. (2), pp. 63-91, Riyadh (1426H. /2006).

[2]. Anand, M., (2004).Factors Influencing Dividend Policy Decisions of Corporate India. The ICFAI Journal of APPLIED FINANCE volume 10 No. 2 (2004).

[3]. Anil, k., Kapoor, S., (2008).Determinants of Dividend Payout Ratios-A Study of Indian Information Technology Sector.International Research Journal of Finance and Economics ISSN 1450-2887 Issue 15 (2008)

[4]. Asquith, P., Mullin, D., (1983). The Impact of Initiating Dividend Payments on Shareholders' Wealth.The Journal of Business, Vol. 56, No. 1 (Jan., 1983), pp. 77-96

[5]. Auret, C., Sinclaire, R., (2006). "Book-to-market ratio and returns on the JSE”. Investment Analysts Journal - No. 632006

[6]. Azhagaiah, R., Priya, S., (2008). “The Impact of Dividend Policy on Shareholders' Wealth".International Research Journal of Finance and Economics. ISSN 1450-2887 Issue 20 (2008)

[7]. Barber, B., Lyon, J., (1997). Firm size, Book-to-market ratio, and security returns: A holdout sample of financial firms. The journal of finance, vol.52, No.2 (Jun., 1997), 875-883.

[8]. Below, S., Johnson, K. (1996). An analysis of shareholder reaction to dividend announcement in bull and bear markets.Journal of Financial and Strategic Decisions 1996Volume 9 Number 3

[9]. Bogoslaw, D. (October 1, 2009). November 1, 2009, Dividends: Smart Plays for Tight Times. Retrieved November 1, 2009, from http://www.businessweek.com/investor/content/oct2009/pi2009101_095000.htm

[10]. Cohn, M., (2005).A pedagogical method of dealing with students' risk anxiety of investing in the stock market. Journal of College Teaching and Learning - May 2005 Volume 2, Number 5

[11]. De, S., (1975). Dividends and Stock Prices: The Indian Experience. Economic and Political Weekly, Vol. 10, No. 36 (Sep. 6 , 1975), pp. M62-M63+M65- M67+M69+M71-M72

[12]. Dempsey, M., (2006).The Book-to-Market Equity Ratio as a Proxy for Risk: Evidence from Australian Markets.Department of Accounting and Finance, Monash University Australia

[13]. Desai, H., Jain, P.C, (1997). Long-Run Common Stock Returns following Stock Splits and Reverse Splits. Journal of Business, 1997, vol. 70, no. 3 
[14]. Dyl, E., A., Elliott, W, .B, 2006).The Share Price Puzzle.Journal of Business, 2006, vol. 79, no. 4

[15]. Elfakhani, S., (1995).An empirical examination of the information content of balance sheet and dividend announcement: A signaling approach. Journal of Financial and Strategic Decisions1995Volume 8 Number 2

[16]. Eriotis, N., (2005). The Effect of Distributed Earnings and Size of the Firm to Its Dividend Policy: Some Greek Data. International Business \& Economics Journal - January 2005 Volume 4, Number 1

[17]. Farsi, F., Geary, A., Moser, J., (2004).The relationship between dividend and earnings. The journal for economics educators Volume $4 \square$ Number 4 (2004)

[18]. Garrett, I., Priestley, R., (2000). Dividend Behavior and Dividend Signaling.The Journal of Financial and Quantitative Analysis, Vol. 35, No. 2 (Jun., 2000), pp. $173-189$

[19]. Go, P. (2009, May 4). How Dividend Payout is Determined. Retrieved November 1, 2009, from http://ezinearticles.com/?How-Dividend-Payout-is-Determined\&id=2301714 